\title{
Experimental investigation of an active inclined solar panel absorber solar still - Energy and Exergy analysis
}

\author{
Mohamed Thalib Mohamed Rafeek \\ B S Abdur Rahman Crescent Institute of Science \& Technology \\ Vimala Muthu \\ R.M.K college of Engineering and Technology \\ Muthu Manokar Athikesavan ( $\sim$ a.muthumanokar@gmail.com ) \\ BS Abdur Rahman University https://orcid.org/0000-0001-7523-6796 \\ Ravishankar Sathyamurthy \\ KPRIET: KPR Institute of Engineering and Technology \\ Abd Elnaby Kabeel \\ Tanta University
}

\section{Research Article}

Keywords: fresh water, active inclined solar still, effect of mass flow rates, enhancement of panel efficiency, PV thermal and exergy analysis

Posted Date: May 13th, 2021

DOI: https://doi.org/10.21203/rs.3.rs-451870/v1

License: @ (1) This work is licensed under a Creative Commons Attribution 4.0 International License. Read Full License

Version of Record: A version of this preprint was published at Environmental Science and Pollution Research on October 2nd, 2021. See the published version at https://doi.org/10.1007/s11356-021-16444-3. 


\section{Abstract}

The objective of the current study is to investigate the performance of the Inclined Solar Panel Basin Still (ISPBS) incorporated with a Spiral Tube Collector (STC) for various mass flow rates of water $\left(\mathrm{m}_{\mathrm{f}}\right)$. The maximum potable water yield of $8.1,6.9$ and $6.1 \mathrm{~kg}$ is obtained for different mass flow rates of $1.8,3.2$ and $4.7 \mathrm{~kg} / \mathrm{hr}$ in each instance. Also, for $\mathrm{m}_{\mathrm{f}}$ values of $1.8,3.2$ and $4.7 \mathrm{~kg}$ per hour, the daily average energy and exergy efficiency of the ISPBS is recorded to be 47.9, 39.3 and $31.02 \%$ and $9.8,7.9$ and $5.6 \%$ in each instance. The average electrical, energy and exergy efficiency of the PV panel is noted to be $6.5,7.1$ and $7.5 \%, 15.67,17.1$ and $18.04 \%$ and $20.03,22.21$ and $23.36 \%$ for $m_{f}$ values of $1.8,3.2$ and $4.7 \mathrm{~kg} / \mathrm{hr}$ in each instance. The rise in $\mathrm{m}_{\mathrm{f}}$ causes a drop in the fresh water production yield, thermal, exergy and overall thermal effectiveness and an enhancement in the power production of the panel, electrical, thermal, exergy and overall exergy efficiency of the system.

\section{Introduction}

Our planet is globally marching towards ultimate progression in all aspects. This causes increasing demands for necessities in the human life. (El-Agouz et al. 2018, Manokar et al. 2018, Manokar et al. 2018a) Greater desires and demands are causing the depletion of our natural resources. The needs of the industrial enterprises are fulfilled by the resources which would disappear in few years. This leads to the need for switching our concentration towards inexhaustible energy sources to meet our needs and protecting our conventional sources of energy. (Manokar et al. 2019, Kabeel et al. 2019, Manokar et al. 2017) Water can be desalinated using the solar still and the power requirements can be met with Photovoltaic (PV) panel. These methods provide great hope to safeguard our future resource requirements. Commercially, PV panel is coupled with solar still to produce electricity and also fresh water at the same time. Scarcity of potable water and absence of electrical facilities can be tackled by this technique (Raj et al. 2019, Manokar et al. 2017a, Manokar et al. 2018b, El-Agouz et al. 2018a).

(Al-Nimr et al. 2018) introduced a distillation unit model with photovoltaic/thermoelectric cooler (PV/TEC). The TEC is incorporated to enhance the condensation of water and prevent excessive heating in this model. The daily highest distillate yield of $4.2 \mathrm{~kg}$ was obtained at air temperature of $25^{\circ} \mathrm{C}$, wind rate of $5.5 \mathrm{~m} / \mathrm{s}$ and solar intensity of $1000 \mathrm{~W} / \mathrm{m}^{2} .73 \mathrm{~W}$ of power output was reported to be achieved with photovoltaic cell efficiency of $12.32 \%$. (Al-Nimr et al. 2015) introduced a novel PV/T distillation unit with SSB still within which the photovoltaic cells were submerged inside the basin. Potable water yield of $6.8 \mathrm{~L} / \mathrm{m}^{2} /$ day was achieved. (Al-Nimr and Dahdolan 2016) then designed a novel PV/T unit which uses the eliminated heat energy for the purpose of distillation. The model is incorporated with an evaporator and a condenser to augment its performance.

(Layek et al. 2018) investigated the yield and efficiency of basin type solar stills by making use of black toner, black ink and black dye as absorptive substances. It was noted that the stills with black ink, dye and toner showed highest energy efficiency of $41.3 \%, 43.42 \%$ and $45.79 \%$ and exergy efficiency of $5.91 \%, 6.34 \%$ and $7.10 \%$ in each instance. (Panchal et al. 2018) did a relative study between a triangular pyramid still under active and passive mode to analyze the exergy and economic factors. The energy efficiency was reported to increase at the time of sunset while the values fell during the day. (Madhu et al. 2018) published the exergy of Conventional Solar Still (CSS) integrated with sand heat energy storage arrangement. The distillate yield from the still with energy storing substance was reported to be $3.3 \mathrm{~kg} / \mathrm{m}^{2}$ and it showed $30 \%$ greater exergy efficiency in relation to the olden type of still. (Kumar et al. 2017) used a triangular pyramid solar still incorporated with Inclined Solar Still (ISS) to enhance the distilled water production. The percentage rise in yield was recorded to be $79.05 \%$ for the modified still at water depth of $0.02 \mathrm{~m}$ compared to the CSS. (Kabeel et al. 2018) researched about the potable water production by the CSS combined with an ISS. The productivity of the modified still was reported to be $6.2 \mathrm{~kg}$ and it showed $46.23 \%$ greater yield production compared to the CSS at a water depth of 0.02 $\mathrm{m}$.

(Tiwari et al. 2015) studied the developed still integrated with PVT-FPC to determine its yield production, exergy and thermal efficiency. (Singh and Tiwari 2016) examined the cost analysis by combining the energy payback period effect to the PVT-CPC combined solar still in active mode. The percentage rise in yearly yield was reported to be around $5 \%$ for the double slope compared to that of the single slope still at a water depth of $0.14 \mathrm{~m}$. The cost of fresh water production was also noted to be lesser for the double slope still. (Singh and Tiwari 2017) analyzed the PVT-CPC integrated solar still for various economic and production factors. The double slope still showed a percentage rise in distillate yield of $8.56 \%$ in relation to the still with single slope structure at $0.14 \mathrm{~m}$ depth of water. (Singh and Tiwari 2017a) experimented the double slope solar still combined with PVT flat plate collector. The energy producing factor and the life cycle conversion effectiveness were observed to be enhanced while the time of energy payback and the potable 
water price were decreased for the modified still compared to the conventional stills. (Singh and Tiwari 2017b) investigated the energy, exergy and cost of producing distilled water in basin type solar still integrated with tubular collectors. The percentage rise in energy and exergy values in the modified double still slope was recorded to be $6.85 \%$ and $12.30 \%$ in each instance compared to single slope setup. Also the cost of obtaining the distillate yield from the developed still was $15.19 \%$ lower compared to the olden type of stills. (Ahmed and Shinichi 2020) studied the stepped solar still model incorporated with reflectors and copper fins. It was noted that this model showed $129 \%$ enhancement in yield when compared to the conventional model. The daily water production reached up to 8.28 L/day. From the referred theses, it is observed that only a few researches were conducted using ISS in active mode. Here, this research is primarily aimed at the investigation of ISPBS integrated with STC at varied mass flow rate of water.

\section{Diagram And Fabrication Of The Suggested Model}

The illustrative diagram and the experimental organization of the ISPBS combined with STC (AISS) are depicted in Figs. 1 and 2. The STC is incorporated along with the ISPBS and various parameters are analyzed for different input mass flow rates of water $\left(m_{f}\right) .181$ $\mathrm{cm}$ (Length) $\times 92 \mathrm{~cm}$ (Width) $\times 15 \mathrm{~cm}$ (Height) are the measurements of the still covered by $0.4 \mathrm{~cm}$ wide glass. The saline water at constant $m_{f}$ reaches the solar heater from the storage tank. The absorber tube in the heater heats up the water flowing through it and delivers it to the still. The construction of the STC solar water heater was done with a flat solar collector (spiral), regulation valve and a tank for storage. The solar collector has dimensions of $90 \mathrm{~cm}(\mathrm{~L}) \times 60 \mathrm{~cm}(\mathrm{~W}) \times 0.4 \mathrm{~cm}(\mathrm{H})$ and its construction was done using a wooden container $(2 \mathrm{~cm}$ thick) along with a $0.4 \mathrm{~cm}$ wide cover glass. The heater includes a copper tube $(0.1 \mathrm{~cm}$ thick) having three windings each of diameter $1 \mathrm{~cm}$ and separated from each other by $5 \mathrm{~cm}$. A $5000 \mathrm{ml}$ plastic columnar reservoir tank is used to store water.

\section{Outcomes And Analyses}

\subsection{Hourly changes in various parameters of the AISS}

The alterations in the solar radiation and air temperature of the STC incorporated still are depicted in Fig. 3(a) and (b). The solar radiation rose to attain its highest value until 1 P.M after which it started to fall. The highest values of solar radiation were recorded to be 880,870 and $900 \mathrm{~W} / \mathrm{m}^{2}$ on $1.8 .2017,4.8 .2017$ and 6.8 .2017 in each instance. The average solar radiation of $699 \mathrm{~W} / \mathrm{m}^{2}$ was observed on 1.8.2017 while on 4.8.2017, it was noted to be $696 \mathrm{~W} / \mathrm{m}^{2}$ and $719 \mathrm{~W} / \mathrm{m}^{2}$ on $6.8 .2017 .33,32$ and $35^{\circ} \mathrm{C}$ were the highest air temperatures recorded on 1.8.2017, 4.8.2017 and 6.8.2017 in each instance. The average air temperature per day was noted to be about 30 to $33^{\circ} \mathrm{C}$.

The alterations in the wind speed and the temperature of the cover glass of the collector of the AISS are depicted in Fig. 4 (a) and (b). The average velocity of wind was recorded to be $1.1,1.8$ and $2 \mathrm{~m} / \mathrm{s}$ on 1.8.2017, 4.8.2017 and 6.8.2017 on each instance. The highest temperature of the cover glass of the collector of $53^{\circ} \mathrm{C}$ was observed on 1.8 .2017 while on 4.8 .2017 , it was noted to be $52^{\circ} \mathrm{C}$ and $47^{\circ} \mathrm{C}$ on 6.8.2017. The average temperature of the collector cover per day was recorded to be $47.1,45$ and $43.2^{0} \mathrm{C}$ on 1.8 .2017 , 4.8.2017 and 6.8.2017 on each instance.

\subsection{Influence on glass, basin and brackish water temperature due to the mass flow rates}

The alterations in the basin temperature of the AISS with respect to the $\mathrm{m}_{\mathrm{f}}$ of water are depicted in Fig. 5 (a). The temperature of the basin rose with rise in solar irradiation to attain its highest value until 2 P.M after which it started to fall. For water $m_{f}$ values of $1.8,3.2$ and $4.7 \mathrm{Kg} / \mathrm{hr}$, the highest temperature of the basin was observed to be 72,69 and $65^{\circ} \mathrm{C}$ in each instance. The average temperature of the basin per day was noted to be $62.1,59.1$ and $55.2^{\circ} \mathrm{C}$ for $\mathrm{m}_{\mathrm{f}}$ values of $1.8,3.2$ and $4.7 \mathrm{Kg} / \mathrm{hr}$ in each instance. The basin temperature fell by $4.8 \%$ when $m_{f}$ rose from $1.8 \mathrm{Kg} / \mathrm{hr}$ to $3.2 \mathrm{Kg} / \mathrm{hr}$ and by $11.1 \%$ when $\mathrm{m}_{\mathrm{f}}$ rose to $4.7 \mathrm{Kg} / \mathrm{hr}$ from $1.8 \mathrm{Kg} / \mathrm{hr}$. So, from the noted values, it is seen that the basin temperature falls when the $\mathrm{m}_{\mathrm{f}}$ of water is raised as a large quantity of water tends to absorb the temperature from the basin.

The alterations in the temperature of brackish water of the AISS with respect to the $m_{f}$ of water are depicted in Fig. 5 (b). Similar to the basin temperature, the brackish water temperature also rose up to attain its highest value until 2 P.M after which it started to fall. For 
water $m_{f}$ values of $1.8,3.2$ and $4.7 \mathrm{Kg} / \mathrm{hr}$, the highest temperature of saline water was observed to be 76,73 and $70^{\circ} \mathrm{C}$ in each instance. The average temperature of saline water per day was noted to be $65.7,63$ and $60.7^{\circ} \mathrm{C}$ for $\mathrm{m}_{\mathrm{f}}$ values of $1.8,3.2 \mathrm{and} 4.7 \mathrm{Kg} / \mathrm{hr}$ in each instance. The average water temperature per day fell by $4.1 \%$ when $m_{f}$ rose from $1.8 \mathrm{Kg} / \mathrm{hr}$ to $3.2 \mathrm{Kg} / \mathrm{hr}$ and by $7.6 \%$ when $\mathrm{m}_{\mathrm{f}}$ rose to $4.7 \mathrm{Kg} / \mathrm{hr}$ from $1.8 \mathrm{Kg} / \mathrm{hr}$. So, from the noted values, it is seen that the increased $m_{\mathrm{f}}$ leads to the flow of increased quantity of water which in turn causes inefficient heating and ultimately reduces the productivity of the still. Least $m_{f}$ rises the time of contact between the brackish water and absorber plate which leads to efficient heating and enhanced productivity.

\subsection{Influence on the distillate yield, thermal and energy efficiency due to the mass flow rates}

The alterations in the distillate yield of the AISS with respect to the $m_{f}$ of water are depicted in Fig. 6 . Highest daily productivity is achieved only when the water $m_{f}$ is the lowest as water temperature in the AISS can be enhanced only in this condition. The potable water yield was recorded to be $8.1,6.9$ and $6.1 \mathrm{Kg}$ for $\mathrm{m}_{\mathrm{f}}$ values of $1.8,3.2$ and $4.7 \mathrm{Kg} / \mathrm{hr}$ in each instance. The daily productivity fell by $14.68 \%$ when $m_{f}$ rose from $1.8 \mathrm{Kg} / \mathrm{hr}$ to $3.2 \mathrm{Kg} / \mathrm{hr}$ and by $25.3 \%$ when $\mathrm{m}_{\mathrm{f}}$ rose to $4.7 \mathrm{Kg} / \mathrm{hr}$ from $1.8 \mathrm{Kg} / \mathrm{hr}$.

The alterations in the thermal efficiency of the AISS with respect to the $m_{f}$ of water are depicted in Fig. 7 (a). The highest thermal efficiency was recorded to be $68.3,61$ and $54.3 \%$ for $\mathrm{m}_{\mathrm{f}}$ values of $1.8,3.2$ and $4.7 \mathrm{Kg} / \mathrm{hr}$ in each instance. Also, the average thermal efficiency was observed to be $47.9,39.3$ and $31.02 \%$ for the $m_{f}$ values of $1.8,3.2$ and $4.7 \mathrm{Kg} / \mathrm{hr}$ in each instance. The thermal efficiency on average fell by $17.9 \%$ when $m_{f}$ rose from $1.8 \mathrm{Kg} / \mathrm{hr}$ to $3.2 \mathrm{Kg} / \mathrm{hr}$ and by $35.2 \%$ when $\mathrm{m}_{\mathrm{f}}$ rose to $4.7 \mathrm{Kg} / \mathrm{hr}$ from $1.8 \mathrm{Kg} / \mathrm{hr}$.

Thermal effectiveness of the AISS is calculated by,

$$
\eta_{A . t h}=\frac{m_{e w} h_{f g}}{\left[A_{C} \times I_{C}(t)+A_{s} \times I_{S}(t)\right] \times 3600} \times 100
$$

The alterations in the exergy efficiency of the AISS with respect to the $\mathrm{m}_{\mathrm{f}}$ of water are depicted in Fig. 7(b). The highest exergy efficiency per hour was recorded to be $15.5,12.5$ and $10.2 \%$ for $m_{f}$ values of $1.8,3.2$ and $4.7 \mathrm{Kg} / \mathrm{hr}$ in each instance. The average exergy efficiency was observed to be $9.8,7.9$ and $5.6 \%$ for the $m_{f}$ values of $1.8,3.2$ and $4.7 \mathrm{Kg} / \mathrm{hr}$ in each instance. Rise in $m_{f}$ led to the fall in exergy efficiency due to the above cited reason. The exergy efficiency fell by $19.3 \%$ when $\mathrm{m}_{\mathrm{f}}$ rose from $1.8 \mathrm{Kg} / \mathrm{hr}$ to 3.2 $\mathrm{Kg} / \mathrm{hr}$ and by $43.7 \%$ when $\mathrm{m}_{\mathrm{f}}$ rose to $4.7 \mathrm{Kg} / \mathrm{hr}$ from $1.8 \mathrm{Kg} / \mathrm{hr}$.

The exergy efficiency of the AISS is calculated using,

$$
\eta_{a, e}=\frac{e_{a, o u t}}{e_{p . i n}+e_{f p c . i n}}
$$

Active exergy output of an ISPBS is determined using],

$$
e_{a . \text { out }}=\left(m_{d^{x}} h_{f g}\right)\left(1-\left[\frac{T_{a}+273}{T_{W}+273}\right]\right)
$$

Active exergy input of an ISPBS is calculated using,

$$
e_{a . \text { in }}=e_{p . i n}+e_{f p c . i n}
$$

Exergy input to STC is determined using,

$$
e_{f p c . i n}=Q_{u}\left[1-\frac{T_{a}+273}{T_{W}+273}\right]
$$

Useful heat gained by STC is calculated using, 


$$
Q_{u}=\left(I x A_{p}\right)-q
$$

Heat lost from STC is determined using,

$$
q=U A\left(T_{b}-T_{a}\right)
$$

\subsection{Influence on power production, electrical, thermal and exergy effectiveness of the PV panel due to mass flow rates}

Figure $8(a, b, c)$ depicts the alterations in the panel temperature, PV panel electrical, energy and exergy effectiveness for an AISS at various $m_{f}$. From the Fig. $8(a, b, c)$ it is recorded that when the $m_{f}$ increases, the panel temperature falls.

The PV panel reached the highest temperatures of 66,62 and $59^{\circ} \mathrm{C}$ for the $\mathrm{m}_{\mathrm{f}}$ of $1.8,3.2$ and $4.7 \mathrm{Kg} / \mathrm{hr}$ in each instance. The average temperature of the panel per day at $m_{f}$ of $1.8,3.2$ and $4.7 \mathrm{Kg} / \mathrm{hr}$ is 57,53 and $48.8^{\circ} \mathrm{C}$ in each instance. Increasing the $m_{f}$ of an ISPB still integrated with STC results in reduction in panel temperature. The average temperature of the panel per day reduces up to 7.02 and $14.42 \%$ when the $m_{f}$ of water rises from 1.8 to $3.2 \mathrm{Kg} / \mathrm{hr}$ and 1.8 to $4.7 \mathrm{Kg} / \mathrm{hr}$ in each instance. The highest hourly PV panel power generation and efficiency from an AISS at 1.8, 3.2 and $4.7 \mathrm{Kg} / \mathrm{hr}$ is recorded to be $68.4,71.4,74.1 \mathrm{~W}$ and $8.5,8.7,9.2 \%$ in each instance. The average power generation and efficiency in a day are $41.64,46.14,50.44 \mathrm{~W}$ and $6.5,7.1,7.5 \%$ for the $\mathrm{m}_{\mathrm{f}}$ of $1.8,3.2$ and $4.7 \mathrm{Kg} / \mathrm{hr}$ in each instance. Power generation from an AISS is increase with an increase of an $\mathrm{m}_{\mathrm{f}}$ of water. The percentage increase in PV panel power production and efficiency are noted to be 9.78 and $9.1 \%$ when the daily average PV panel temperature decreases up to $7.02 \%$. Similarly, 17.47 and $14 \%$ rise in PV panel power production and efficiency are recorded when the daily average PV panel temperature decreases up to $14.42 \%$.

The electrical efficiency of the solar panel is calculated using,

$$
\eta_{p \text { velectrical }}=\frac{F F * V * I}{I_{S}(t) * A_{s}} \times 100 \%
$$

PV thermal effectiveness has the similar characteristics as the electrical efficiency of the solar panel and it reaches its peak value of $20.45,20.67$ and $21.67 \%$ at $m_{f}$ of $1.8,3.2$ and $4.7 \mathrm{Kg} / \mathrm{hr}$, in each instance at 1 P.M. The average daily thermal efficiency of the solar panel is $15.67,17.10$ and $18.04 \%$ at $m_{f}$ at $1.8,3.2$ and $4.7 \mathrm{~kg} / \mathrm{hr}$ in each instance. The constant 0.38 is electric power production effectiveness for a conventional power plant model. It is used to convert the electrical energy produced from PV panel to its equivalent thermal energy.

The thermal efficiency of the PV panel is determined using,

$$
\eta_{p v t h e r m a l}=\frac{F F * V_{o c} * I_{s C}}{0.38 I_{S}(t) * A_{S}} \times 100 \%
$$

From Fig. $8(a, b, c)$ it can be seen that the solar panel has higher exergy efficiency at least solar panel temperature. The average PV panel exergy efficiency in a day is $20.03,22.21$, and $23.36 \%$ at $m_{f}$ at $1.8,3.2$ and $4.7 \mathrm{Kg} / \mathrm{hr}$ in each instance. When the $\mathrm{m}_{\mathrm{f}}$ of water increased from 1.8 to $3.2 \mathrm{Kg} / \mathrm{hr}$ and from 1.8 to $4.7 \mathrm{Kg} / \mathrm{hr}$ the exergy efficiency of a PV panel enhanced up to 9.8 and $14.3 \%$ in each instance.

The exergy efficiency of the solar panel is calculated using,

$$
\eta_{\text {pvexergy }}=\frac{F F * V_{o C} * I_{S C}-V I}{0.933 I_{S}(t) * A_{S}} \times 100 \%
$$

\subsection{Hourly variations in the overall thermal and exergy efficiency of an AISS}

The alterations in the overall thermal efficiency of an AISS (thermal efficiencies of an ISPB still and a PV panel) at various $\mathrm{m}_{\mathrm{f}}$ are depicted in Fig. 9 (a). The overall thermal efficiency of the AISS is the highest when the $m_{f}$ is the least. When the $m_{f}$ rises, the thermal efficiency of the ISPB still decreases, whereas there is an increase in thermal efficiency of the PV panel. The highest overall thermal

Page 5/17 
efficiency of the system per hour is $88.72,76.76$ and $76.01 \%$ at $m_{f}$ at $1.8,3.2$ and $4.7 \mathrm{Kg} / \mathrm{hr}$ in each instance. The average overall thermal efficiency of the system in a day is $64.91,58.75$ and $52.95 \%$ at $m_{f}$ at $1.8,3.2$ and $4.7 \mathrm{Kg} / \mathrm{hr}$ in each instance. It is noted that there is a $9.5 \%$ and $18.4 \%$ reduction in the overall thermal efficiency of the system when the $\mathrm{m}_{\mathrm{f}}$ increases from $1.8 \mathrm{to} 3.2 \mathrm{Kg} / \mathrm{hr}$ and from $1.8 \mathrm{Kg} / \mathrm{hr}$ to $4.7 \mathrm{Kg} / \mathrm{hr}$ in each instance.

The overall thermal effectiveness of an AISS is calculated by,

$$
\eta_{\text {overalla.thermal }}=\frac{m_{e w} h_{f g}}{\left[A_{C} \times I_{C}(t)+A_{S} \times I_{S}(t)\right] \times 3600} \times 100+\frac{F F * V_{o C} * I_{S C}-V I}{0.933 I_{S}(t) * A_{S}} \times 100 \%
$$

Figure 9 (b) depicts the overall exergy efficiencies of an AISS at various $m_{f}$. The average exergy efficiency of the AISS in a day are recorded to be $9.8,7.9$ and $5.6 \%$ and average PV panel exergy efficiency of the model per day is about $20.03,22.21$ and $23.36 \%$ and the overall average exergy efficiency of the AISS is $29.97,30.25$ and $29.07 \%$ at $\mathrm{m}_{\mathrm{f}}$ at $1.8,3.2$ and $4.7 \mathrm{Kg} / \mathrm{hr}$ in each instance. The daily average exergy efficiency of the AISS tends to reduce when the $m_{f}$ increases whereas the daily average exergy efficiency of the PV panel is enhanced. The decrease in exergy efficiency of the AISS and increases in panel exergy efficiency will result in nearly equal overall exergy efficiency for all the $\mathrm{m}_{\mathrm{f}}$.

The overall exergy effectiveness of an AISS is determined using,

$$
\frac{\left(m_{d} * h_{f g}\right)\left(1-\left[\frac{T_{a}+273}{T_{w}+273}\right]\right)}{\left(A_{S} * I_{t}\right)\left[1+\left(\frac{1}{3}\left[\frac{T_{a}+273}{6000}\right]^{4}-\frac{4}{3}\left[\frac{T_{a}+273}{6000}\right]\right)\right]+Q_{u}\left[1-\frac{T_{a}+273}{T_{W}+273}\right]}+\frac{F F * V_{o C} * I_{S C}-V I}{0.933 I_{S}(t) * A_{S}} \times 100 \%
$$

\subsection{Relative study between the productivity of various PV/T solar stills}

A relative study on the amount of distillate yield from various hybrid PV/T solar still was done and noted in Table 1. (Dev \& Tiwari 2010) analyzed the performance of the solar still integrated with FPC and PV module and obtained a yield of $7.223 \mathrm{~kg} / \mathrm{m}^{2}$. (Kumar \& Tiwari 2009, Kumar \& Tiwari <2010) recorded productivity in the range of $6-10 \mathrm{~kg} / \mathrm{m}^{2}$ from their hybrid active solar still. A yield of 7.9 $\mathrm{kg} / \mathrm{m}^{2}$ was noted in (Gaurr \& Tiwari 2009 study involving hybrid solar still incorporated with collectors. (Saeedi et al. 2015) obtained an enhanced yield of $8.37 \mathrm{~kg} / \mathrm{m}^{2}$ from the active solar still model. (Eltawil et al. 2014) integrated PV, FPC, and heater to the solar still and obtained a yield of about $6-10 \mathrm{~kg} / \mathrm{m}^{2}$. An augmented yield of $12 \mathrm{~L} / \mathrm{m}^{2}$ was obtained from the study of (Abdallah et al. 2009) using solar still with superheat conduction metal vacuum tube. (Singh et al. 2016 recorded productivity in the range of $6-10 \mathrm{~kg} / \mathrm{m}^{2}$ from their solar still with double hybrid PVT collectors. (Moh'd \& \& Al-Ammari 2016) examined the functioning of a solar still having basin attached with PV cells and finned condenser and obtained a yield of $6.8 \mathrm{~kg} / \mathrm{m}^{2}$. The studies using passive solar stills produced yields in the range of $4-5 \mathrm{~kg} / \mathrm{m}^{2}$. (Winston et al. 2018) recorded a productivity of $8.542 \mathrm{~L}$ from the active solar still with effective heating and cover cooling method. A yield of $8.1 \mathrm{~kg}$ was obtained from the current study involving solar still integrated with STC.

Table. 1 Relative study between the productivity of various PV/T solar stills 


\begin{tabular}{|c|c|c|c|}
\hline S.No & Author name & Experimental work done & $\begin{array}{l}\text { Yield } \\
\left(\mathrm{kg} / \mathrm{m}^{2}\right)\end{array}$ \\
\hline 1 & (Dev \& Tiwari 2010) & Solar still with FPC integrated PV module & 7.223 \\
\hline 2 & (Kumar, \& Tiwari 2009) & Active solar still (hybrid PV/T) & $6-10$ \\
\hline 3 & (Gaur \& Tiwari 2010) & $\begin{array}{l}\text { Most effective number of collectors to be used for integrated hybrid PV/T active } \\
\text { solar still }\end{array}$ & 7.9 \\
\hline 4 & (Kumar \& Tiwari 2010) & Hybrid (PV/T) active solar still & 7.22 \\
\hline 5 & (Sarhaddi et al. 2015) & Active solar still (PV/T) & 8.37 \\
\hline 6 & $\begin{array}{l}\text { (Eltawil, \& Omara, } \\
\text { 2014) }\end{array}$ & Solar still utilizing PV, FPC and air heater & $6-10$ \\
\hline 7 & (Abdallah et al. 2009) & Solar still integrated with Super Heat Conduction Metal Vacuum Tube & 12 \\
\hline 8 & (Singh et al. 2016) & Active solar still (two hybrid PVT collectors) & $6-10$ \\
\hline 9 & $\begin{array}{l}\text { (Moh'd A \& Al-Ammari } \\
\text { 2016) }\end{array}$ & $\begin{array}{l}\text { PV cells attached to the solar still basin and integrated with finned condenser at } \\
\text { outer surface }\end{array}$ & 6.8 \\
\hline 10 & (Yari et al. 2016) & Incorporation of solar still and PV module & 4.77 \\
\hline 11 & (Manokar et al. 2018c) & PV panel integration in an inclined solar still in passive mode & 4.4 \\
\hline 12 & (Riahi et al. 2016) & Solar still integrated with AC-heater and PV module & 5.7 \\
\hline 13 & (Winston et al .2018) & PV/T active solar still with effective heating and cover cooling method & 8.542 \\
\hline 14 & (Thalib et al. 2020) & Solar still with PCM & 7.91 \\
\hline 15 & (Yazan et al. 2020) & Inclined solar still incorporated with STC & 8.3 \\
\hline 16 & $\begin{array}{l}\text { Thalib et al. (present } \\
\text { study) }\end{array}$ & PISS integrated with the STC in active mode (present study) & $8.1 \mathrm{~kg}$ \\
\hline
\end{tabular}

\section{Conclusions}

This study is based on the influence of different $m_{f}$ of water in the ISPBS incorporated with the STC unit.

The following results have been reported:-

1. The panel temperature and solar radiation determined the power production from the PV panel. Rise in $\mathrm{m}_{f}$ of brackish water led to the enhancement in the performance of the PV panel but the still performance declined.

2. The daily distillate water output, energy, exergy and overall thermal efficiency of the arrangement falls by $14.68,17.9,19.3$ and 9.5 $\%$ in each instance when water $m_{f}$ is changed to $3.2 \mathrm{Kg} / \mathrm{hr}$ from $1.8 \mathrm{Kg} / \mathrm{hr}$.

3. The power production of the panel, electrical efficiency and exergy efficiency of the system is improved by $9.78,9.1$ and $9.8 \%$ in each instance.

4. The daily distillate productivity, thermal, exergy and overall thermal efficiency of the arrangement falls by $25.3,35.2,43.7$ and 18.4 $\%$ in each instance when water $m_{\mathrm{f}}$ is changed to $4.7 \mathrm{Kg} / \mathrm{hr}$ from $1.8 \mathrm{Kg} / \mathrm{hr}$.

5. The power production of the panel, electrical efficiency and exergy efficiency of the system is improved by $17.47,14$ and $14.3 \%$ in each instance.

\section{Abbreviations}

CSS Conventional Solar Still

PV/T Photovoltaic/Thermal

TEC Thermoelectric Cooler

ISPBS Inclined Solar Panel Basin Still 
STC Spiral Tube Collector

AISS ISPB still combined with STC

$m_{f}$ Mass Flow Rate

PSS Pyramid Solar Still

ISS Inclined Solar Still

STC Spiral Tube Collector

CPC Compound Parabolic Concentrator

\section{Nomenclature}

A - Area (m2)

h- Heat transfer coefficient $\left(\mathrm{W} / \mathrm{m}^{2} \mathrm{~K}\right)$

I - Current $(A)$

$\mathrm{I}(\mathrm{t})$ - Solar intensity $\left(\mathrm{W} / \mathrm{m}^{2}\right)$

$\mathrm{L}-$ Latent heat of Vaporization $(\mathrm{kJ} / \mathrm{kg} \mathrm{K})$

$\mathrm{M}$-Hourly productivity from Solar Still $\left(\mathrm{kg} / \mathrm{m}^{2} \mathrm{~h}\right)$

P- Partial vapor pressure $\left(\mathrm{N} / \mathrm{m}^{2}\right)$

$\mathrm{T}$ - Temperature $\left({ }^{\circ} \mathrm{C}\right)$

V - Voltage (V)

$\eta$ - efficiency (\%)

\section{Subscript}

a- Ambient

c- Convective

d-Daily

e- Evaporative

g-Glass

gi- inner glass

pv-Photovoltaic

s-Surface area of condensing cover

w- Water

\section{Declarations}




\section{Declaration of competing Interest}

The authors declare that there is no competing interest

Availability of data and materials

All data are given in the manuscript

Ethics approval and consent to participate

Not applicable

Consent for publication

Not applicable

Funding

There is no funding received for the research work carried out

\section{Authors Contribution}

Mohamed Thalib Mohamed Rafeek- Writing-review \& editing

Vimala Muthu- Writing-review \& editing

Muthu Manokar Athikesavan- Writing, Formal analysis,

Ravishankar Sathyamurthy- Project administration, Software, review \& editing

Abd Elnaby Kabeel- Data curation, review \& editing

\section{References}

A. Layek, Exergetic analysis of basin type solar still, Eng. Sci. Tech., Int. J. (2018), https://doi.org/10.1016/j.jestch.2018.02.001

Abdallah, S., Abu-Khader, M. M., \& Badran, O. (2009). Performance evaluation of solar distillation using vacuum tube coupled with photovoltaic system. Applied Solar Energy, 45(3), 176.

AlNimr, M. D. A., Al-Ammari, W. A., \& Alkhalidi, A. (2018). A novel hybrid photovoltaics/thermoelectric cooler distillation system. International Journal of Energy Research.

Dev, R., \& Tiwari, G. N. (2010). Characteristic equation of a hybrid (PV-T) active solar still. Desalination, 254(1-3), 126-137.

El-Agouz, E., Kabeel, A. E., Subramani, J., Manokar, A. M., Arunkumar, T., Sathyamurthy, R., \& Babu, D. M. (2018). Theoretical Analysis of Continuous Heat Extraction from Absorber of Solar Still for Improving the Productivity. Periodica Polytechnica Mechanical Engineering, 62(3), 187-195.

El-Agouz, S. A., \& Sathyamurthy, R. (2018). Improvement of humidification-dehumidification desalination unit using a desiccant wheel. Chemical Engineering Research and Design, 131, 104-116.

Eltawil, M. A., \& Omara, Z. M. (2014). Enhancing the solar still performance using solar photovoltaic, flat plate collector and hot air. Desalination, 349, 1-9.

Gaur, M. K., \& Tiwari, G. N. (2010). Optimization of number of collectors for integrated PV/T hybrid active solar still. Applied Energy, 87(5), 1763-1772.

Kabeel AE, Taamneh Y, Sathyamurthy R, Naveen Kumar P,Manokar AM, Arunkumar T. Experimental study on conventional solar still integrated with inclined solar still under different water depth. Heat Transfer-Asian Res. 2018;1-15. https://doi.org/10.1002/htj.21370 
Kabeel, A. E., Manokar, A. M., Sathyamurthy, R., Winston, D. P., El-Agouz, S. A., \& Chamkha, A. J. (2019). A review on different design modifications employed in inclined solar still for enhancing the productivity. Journal of Solar Energy Engineering, 141(3), 031007.

Kumar, P. N., Manokar, A. M., Madhu, B., Kabeel, A. E., Arunkumar, T., Panchal, H., \& Sathyamurthy, R. (2017). Experimental investigation on the effect of water mass in triangular pyramid solar still integrated to inclined solar still. Groundwater for Sustainable Development, 5, 229-234.

Kumar, S., \& Tiwari, A. (2010). Design, fabrication and performance of a hybrid photovoltaic/thermal (PV/T) active solar still. Energy Conversion and Management, 51(6), 1219-1229.

Kumar, S., \& Tiwari, G. N. (2009). Estimation of internal heat transfer coefficients of a hybrid (PV/T) active solar still. Solar Energy, 83(9), 1656-1667.

Madhu, B., Balasubramanian, E., Sathyamurthy, R., Nagarajan, P. K., Mageshbabu, D., Bharathwaaj, R., \& Manokar, A. M. (2018). Exergy analysis of solar still with sand heat energy storage. Applied Solar Energy, 54(3), 173-177.

Manokar, A. M., \& Winston, D. P. (2017). Comparative study of finned acrylic solar still and galvanised iron solar still. Materials Today: Proceedings, 4(8), 8323-8327.

Manokar, A. M., \& Winston, D. P. (2017). Experimental analysis of single basin single slope finned acrylic solar still. Materials Today: Proceedings, 4(8), 7234-7239.

Manokar, A. M., Taamneh, Y., Kabeel, A. E., Sathyamurthy, R., Winston, D. P., \& Chamkha, A. J. (2018). Review of different methods employed in pyramidal solar still desalination to augment the yield of freshwater. DESALINATION AND WATER TREATMENT, 136, 2030.

Manokar, A. M., Vimala, M., Winston, D. P., Ramesh, R., Sathyamurthy, R., Nagarajan, P. K., \& Bharathwaaj, R. (2019). Different parameters affecting the condensation rate on an active solar still-A review. Environmental Progress \& Sustainable Energy. Volume 38, Issue 1, Pages 286-296

Manokar, A. M., Winston, D. P., Kabeel, A. E., \& Sathyamurthy, R. (2018). Sustainable fresh water and power production by integrating PV panel in inclined solar still. Journal of Cleaner Production, 172, 2711-2719.

Manokar, A. M., Winston, D. P., Kabeel, A. E., El-Agouz, S. A., Sathyamurthy, R., Arunkumar, T., \& Ahsan, A. (2018). Integrated PV/T solar still-A mini review. Desalination. 435, 259-267.

Manokar, A. M., Winston, D. P., Mondol, J. D., Sathyamurthy, R., Kabeel, A. E., \& Panchal, H. (2018). Comparative study of an inclined solar panel basin solar still in passive and active mode. Solar Energy, 169, 206-216.

Moh'd A, A. N. (2015). Modeling of a novel concentrated PV/T distillation system enhanced with a porous evaporator and an internal condenser. Solar Energy, 120, 593-602.

Moh'd A, A. N., \& Al-Ammari, W. A. (2016). A novel hybrid PV-distillation system. Solar Energy, 135, $874-883$.

Muthu Manokar, A., Prince Winston, D., Kabeel, A.E., Sathyamurthy, R., \& Arunkumar, T. (2018). Different parameter and technique affecting the rate of evaporation on active solar still-a review. Heat and Mass Transfer, 54: 593-630.

Panchal, H., Taamneh, Y., Sathyamurthy, R., Kabeel, A. E., El-Agouz, S. A., Naveen Kumar, P., \& Bharathwaaj, R. (2018). Economic and exergy investigation of triangular pyramid solar still integrated to inclined solar still with baffles. International Journal of Ambient Energy, 1-6.

Raj S.V., \& Manokar, A. M. (2017). Design and Analysis of Solar Still. Materials Today: Proceedings, 4 (8), $9179-9185$

Riahi, A., Wan Yusof, K., Mahinder Singh, B. S., Isa, M. H., Olisa, E., \& Zahari, N. A. M. (2016). Sustainable potable water production using a solar still with photovoltaic modules-AC heater. Desalination and Water Treatment, 57(32), 14929-14944.

Saeedi, F., Sarhaddi, F., \& Behzadmehr, A. (2015). Optimization of a PV/T (photovoltaic/thermal) active solar still. Energy, 87, $142-152$. 
Shmroukh, A. N., \& Ookawara, S. (2020). Evaluation of Transparent Acrylic Stepped Solar Still Equipped with Internal and External Reflectors and Copper Fins. Thermal Science and Engineering Progress, 100518.

Singh, D. B., \& Tiwari, G. N. (2016). Effect of energy matrices on life cycle cost analysis of partially covered photovoltaic compound parabolic concentrator collector active solar distillation system. Desalination, 397, 75-91.

Singh, D. B., \& Tiwari, G. N. (2017). Energy, exergy and cost analyses of N identical evacuated tubular collectors integrated basin type solar stills: A comparative study. Solar Energy, 155, 829-846.

Singh, D. B., \& Tiwari, G. N. (2017). Enhancement in energy metrics of double slope solar still by incorporating N identical PVT collectors. Solar Energy, 143, 142-161.

Singh, D. B., \& Tiwari, G. N. (2017). Exergoeconomic, enviroeconomic and productivity analyses of basin type solar stills by incorporating N identical PVT compound parabolic concentrator collectors: a comparative study. Energy Conversion and Management, 135, 129-147.

Singh, D. B., Yadav, J. K., Dwivedi, V. K., Kumar, S., Tiwari, G. N., \& Al-Helal, I. M. (2016). Experimental studies of active solar still integrated with two hybrid PVT collectors. Solar Energy, 130, 207-223.

Taamneh, Yazan \& Manokar, A. \& Thalib, M. \& Kabeel, Abd Elnaby \& Sathyamurthy, Ravishankar \& Chamkha, Ali. (2020). Extraction of drinking water from modified inclined solar still incorporated with spiral tube solar water heater. Journal of Water Process Engineering.

Thalib, M. M., Manokar, A. M., Essa, F. A., Vasimalai, N., Sathyamurthy, R., \& Garcia Marquez, F. P. (2020). Comparative Study of Tubular Solar Stills with Phase Change Material and Nano-Enhanced Phase Change Material. Energies, 13(15), 3989.

Tiwari, G. N., Yadav, J. K., Singh, D. B., Al-Helal, I. M., \& Abdel-Ghany, A. M. (2015). Exergoeconomic and enviroeconomic analyses of partially covered photovoltaic flat plate collector active solar distillation system. Desalination, 367, 186-196.

Winston, D. P., Pounraj, P., Manokar, A. M., Sathyamurthy, R., \& Kabeel, A. E. (2018). Experimental investigation on hybrid PV/T active solar still with effective heating and cover cooling method. Desalination, 435, 140-151.

Yari, M., Mazareh, A. E., \& Mehr, A. S. (2016). A novel cogeneration system for sustainable water and power production by integration of a solar still and PV module. Desalination, 398, 1-11.

\section{Figures}




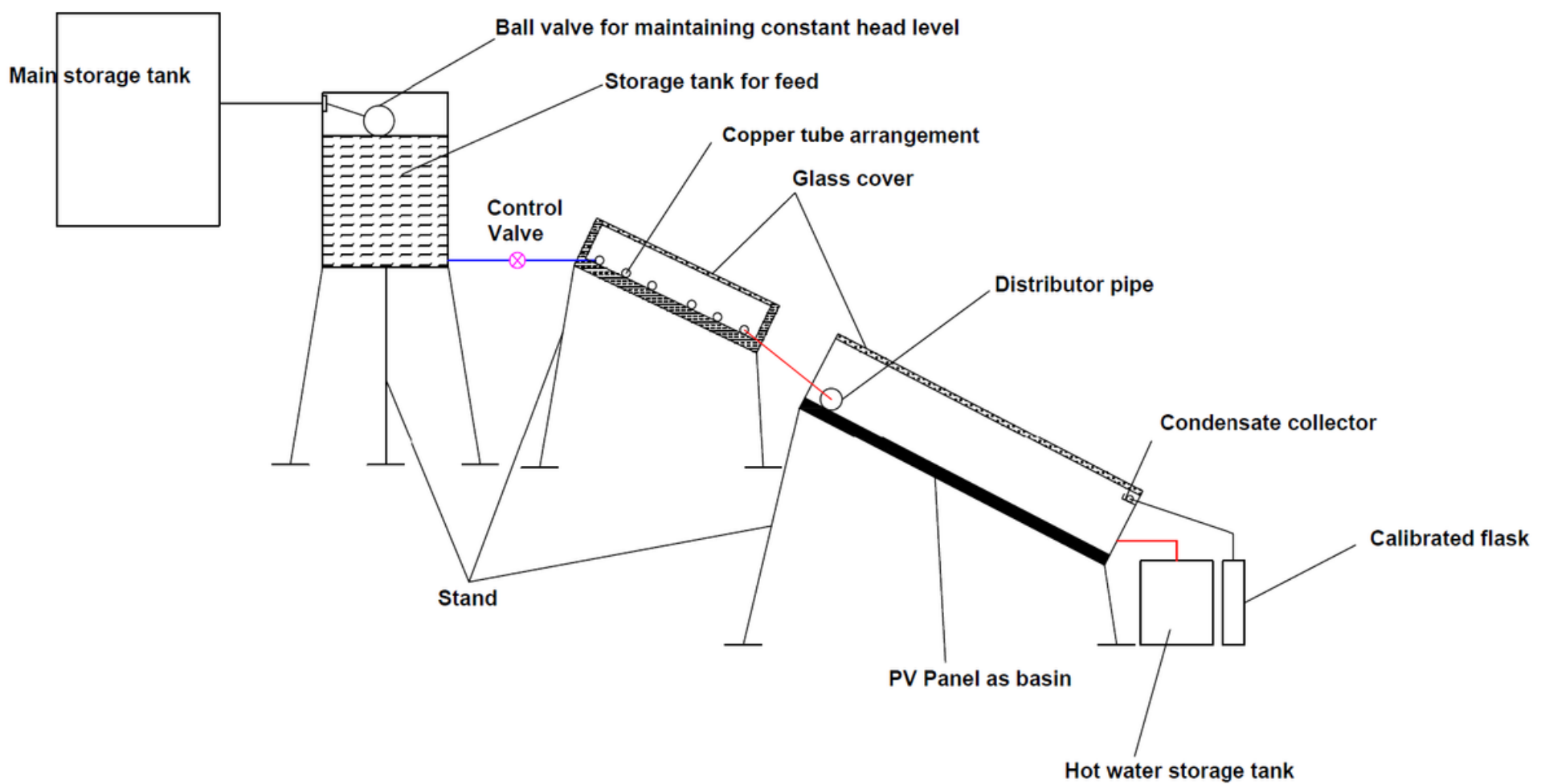

Figure 1

The schematic diagram of the AISS

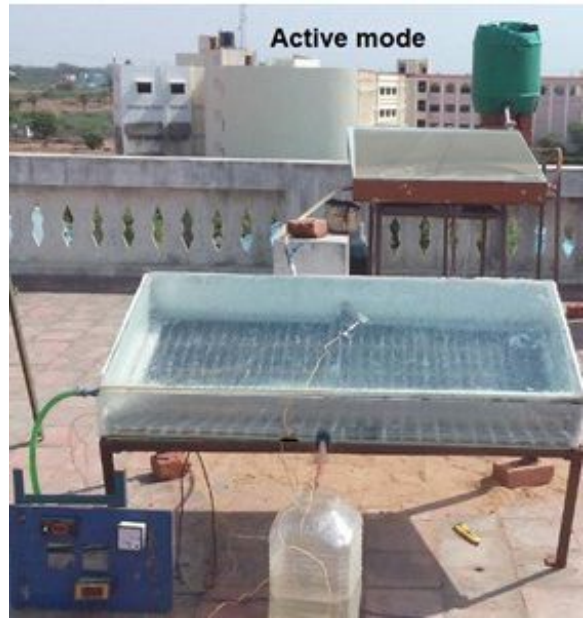

Figure 2

Pictorial view of the AISS 

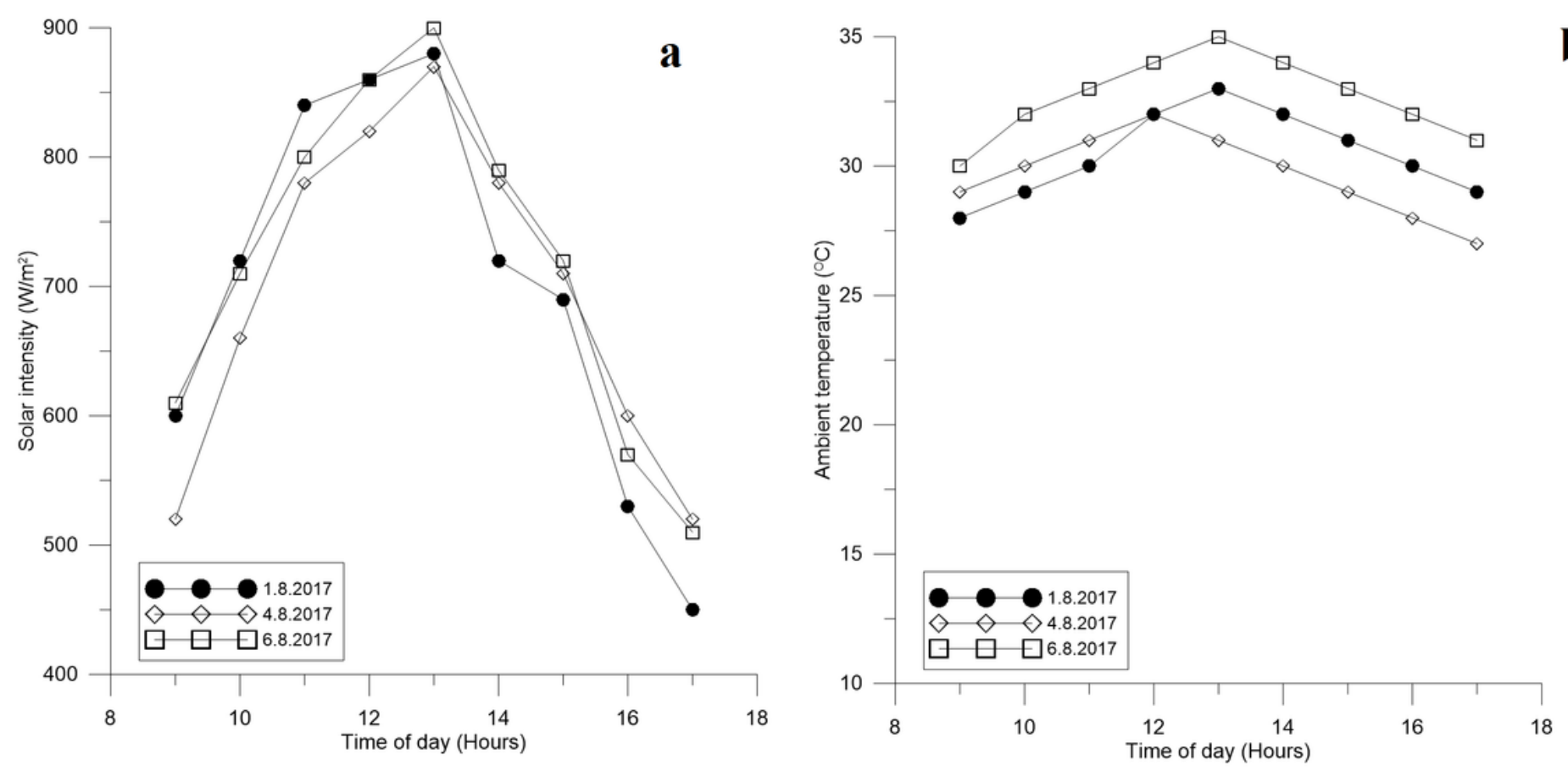

\section{Figure 3}

(a) Diurnal alterations in solar intensity (b) air temperature
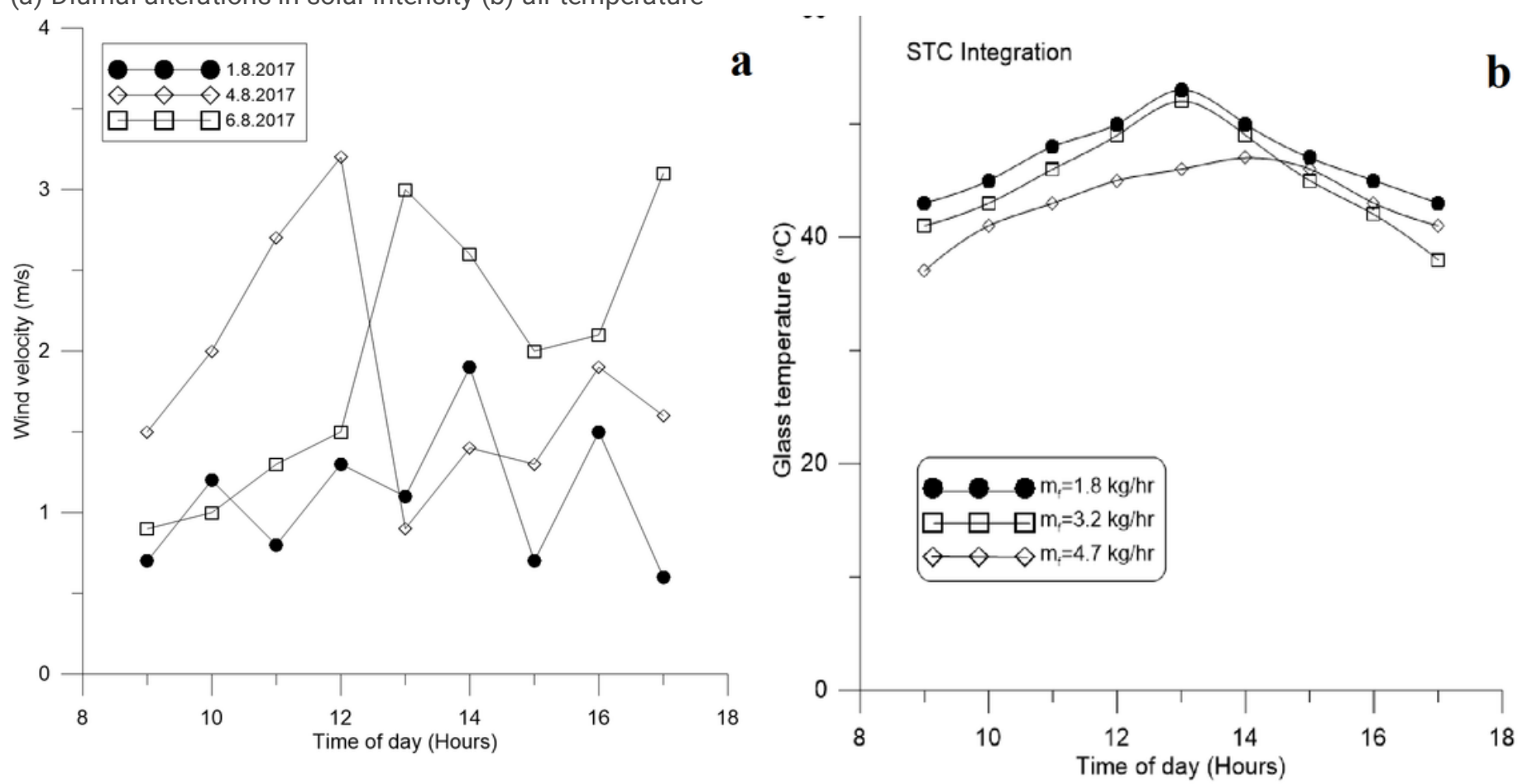

Figure 4

(a) Diurnal alterations in wind speed (b) cover glass temperature 

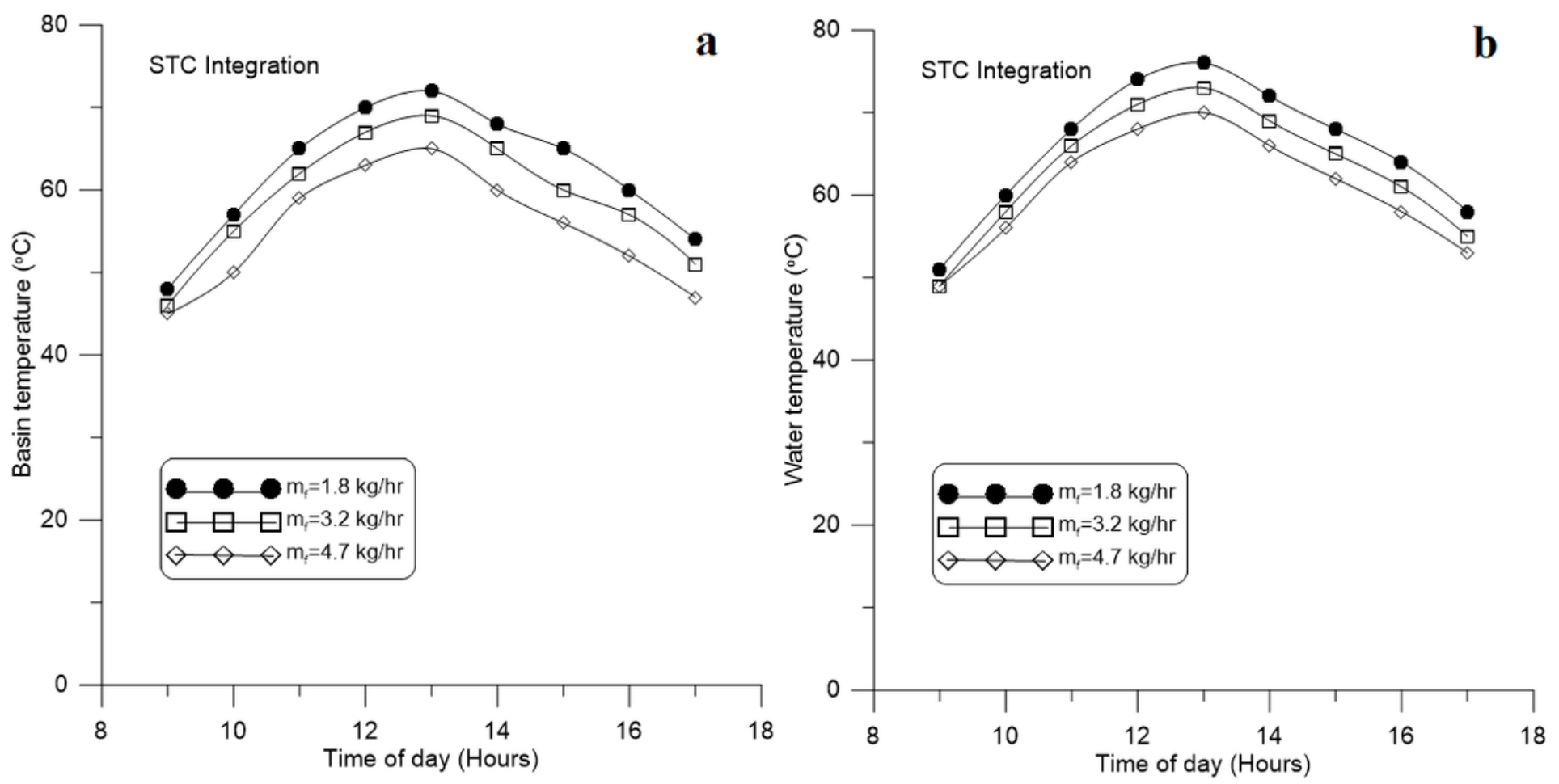

Figure 5

Hourly alterations in (a) basin temperature and (b) water temperature for an AISS

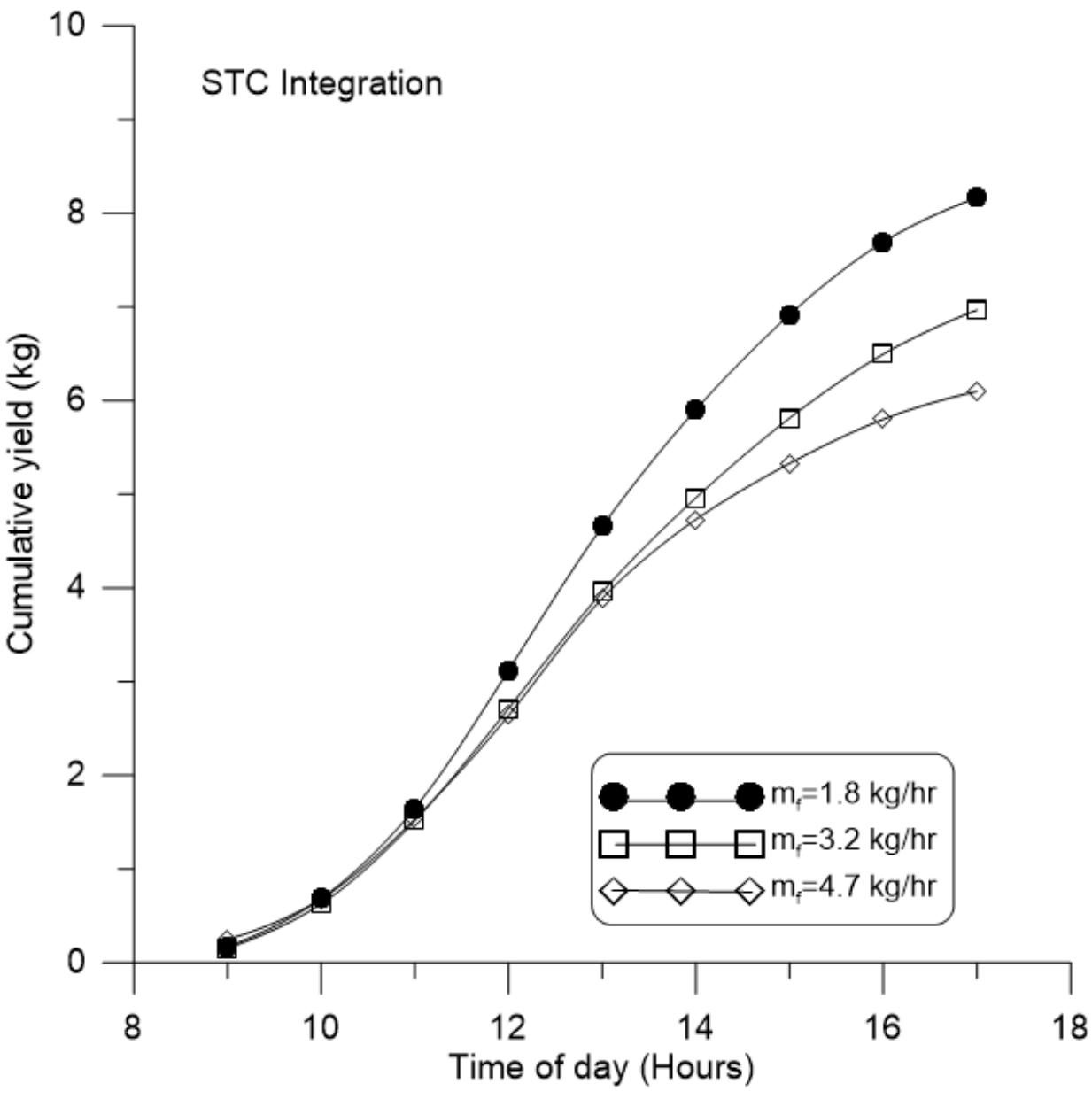

Figure 6 
Hourly alterations in distillate yield for an AISS
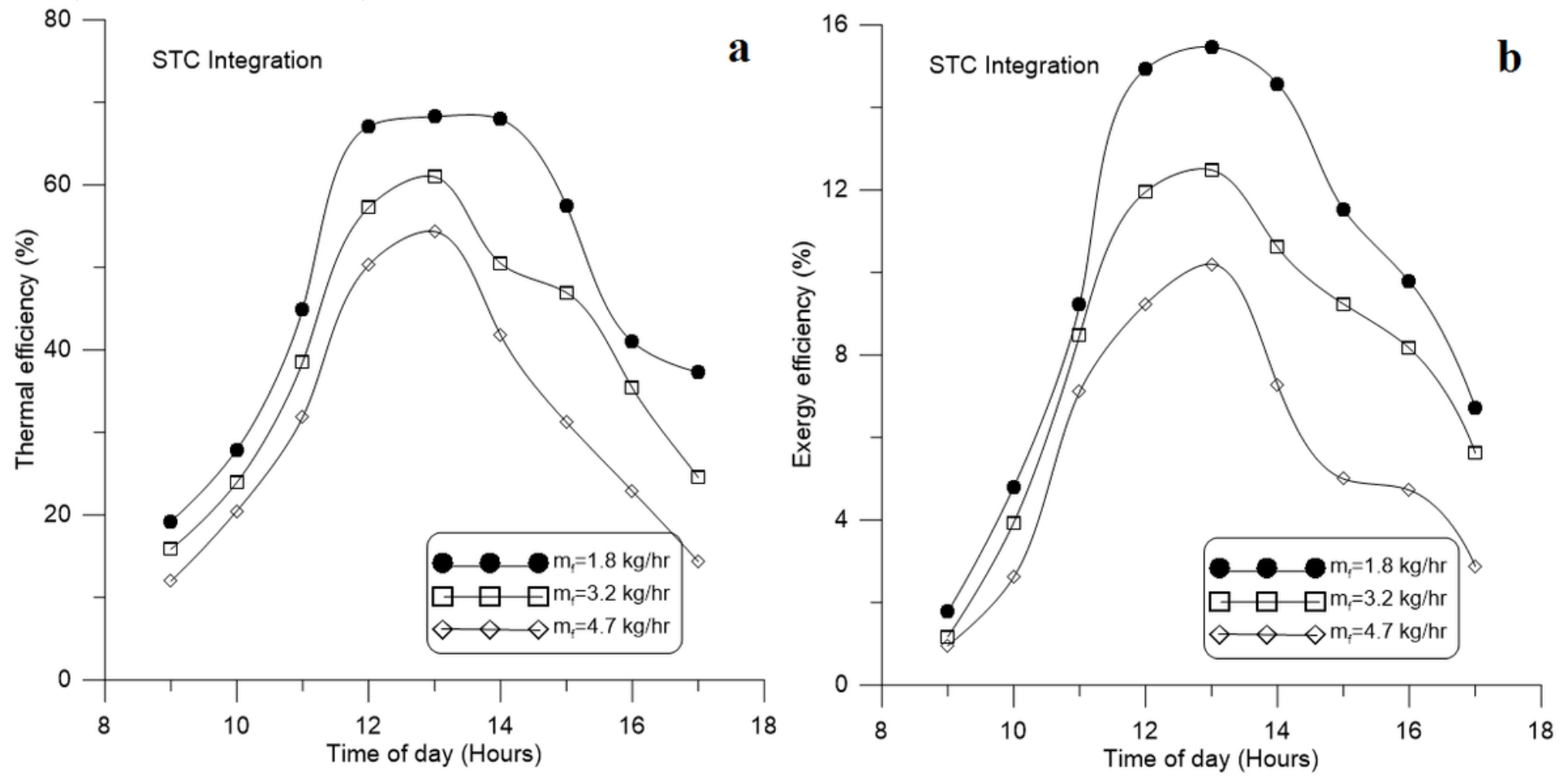

Figure 7

Hourly alterations in (a) thermal efficiency and (b) exergy efficiency for an AISS 


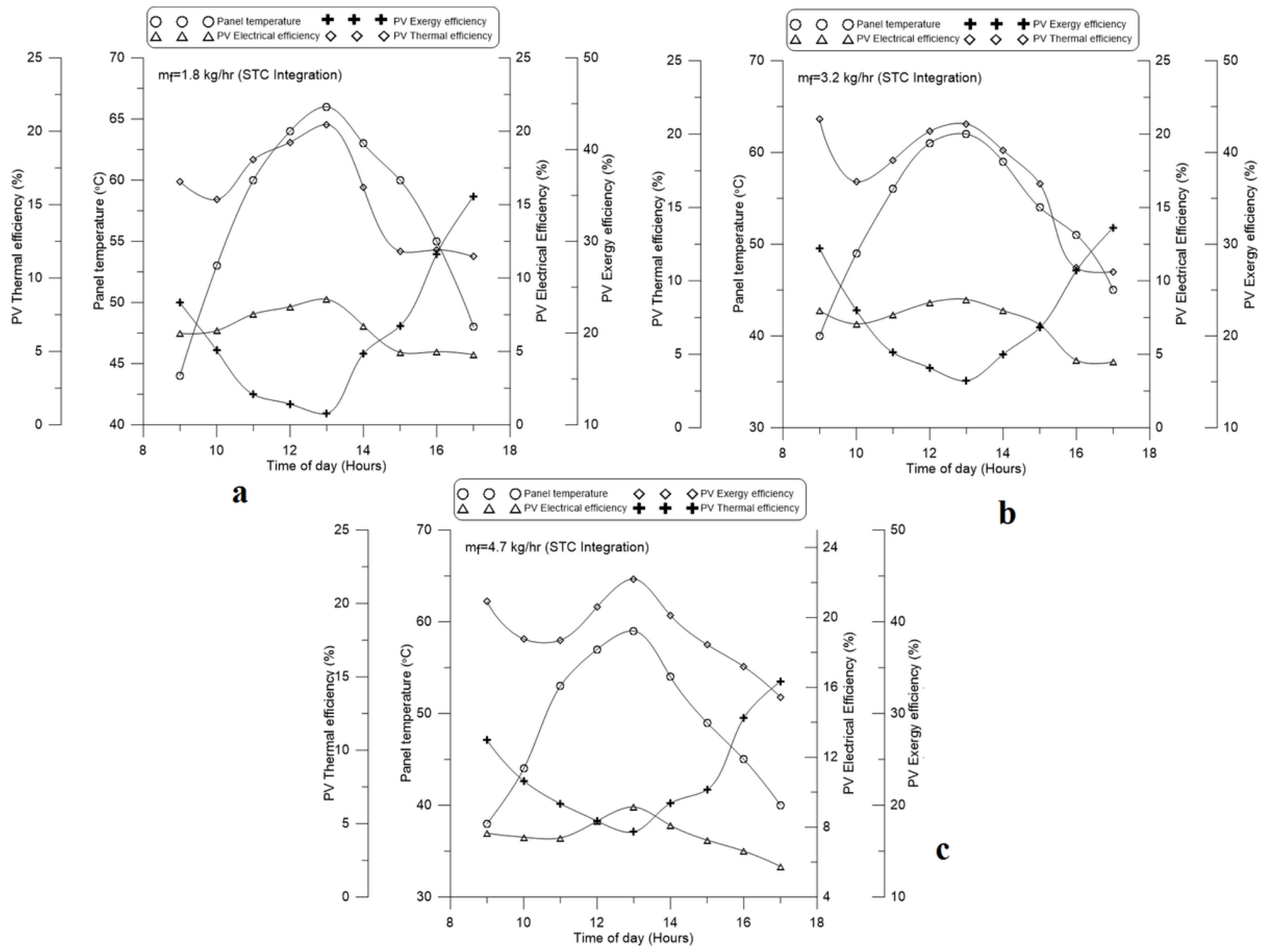

Figure 8

Hourly alterations in panel temperature, PV panel electrical, thermal and exergy efficiency for the mass flow rate of water (a) 1.8 (b) 3.2 (c) $4.7 \mathrm{Kg} / \mathrm{hr}$ 

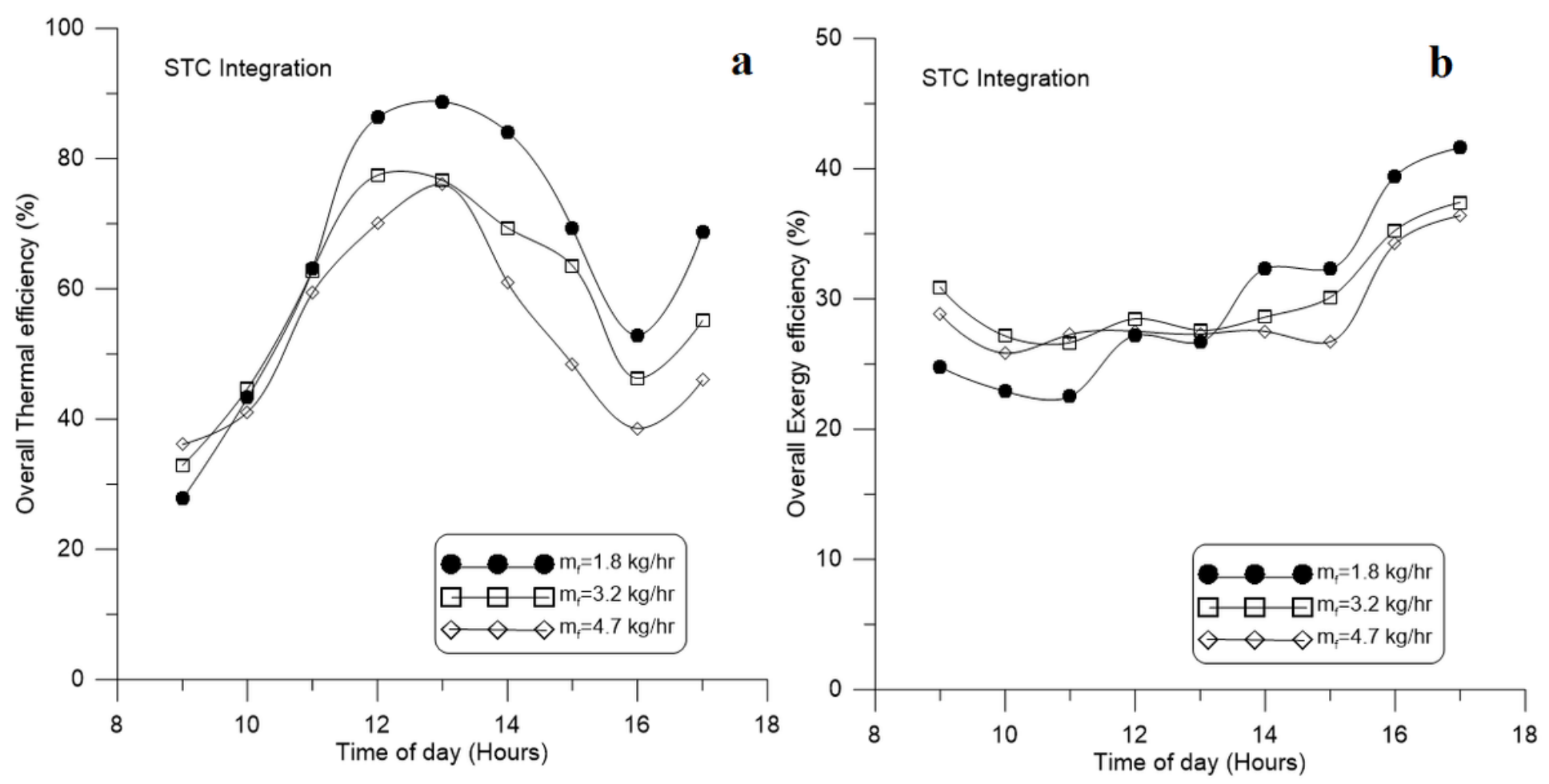

\section{Figure 9}

Hourly alterations in (a) the overall thermal and (b) the overall exergy effectiveness of an AISS 